Copyright (C) 2017 by Academic Publishing House Researcher

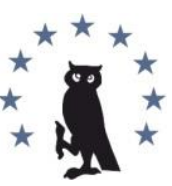

Published in the Russian Federation

European Researcher. Series A

Has been issued since 2010.

ISSN 2219-8229

E-ISSN 2224-0136

2017, 8(1): 18-27

DOI: 10.13187/er.2017.1.18

www.erjournal.ru

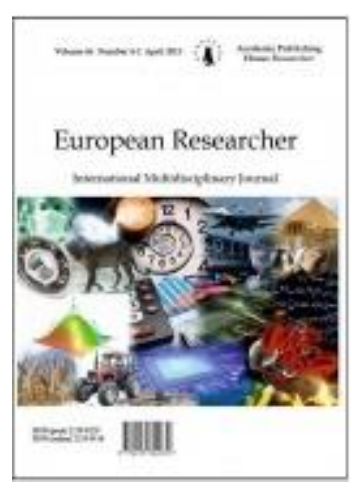

\title{
The Attitude of Parents to Pre-School Inclusive Education for Normal Children and a Child with Down Syndrome
}

\author{
Svetlana A. Gubina a ${ }^{a}$, Anastastasiia N. Serebriakova a , Ekaterina A. Fedorova a \\ ${ }^{a}$ D. Mendeleev University of Chemical Technology of Russia, Russian Federation
}

\begin{abstract}
The object of the research is pre-school inclusive education, this kind of organization of the learning process, in which all children are included in a single system of education and training in educational institutions of General type, regardless of mental, physical and other characteristics, where they receive the necessary support and takes into account their special educational needs (children with Down syndrome). The main source of empirical data quantitative and qualitative methods of the survey of parents and teachers in inclusive groups of kindergartens of Moscow, conducted by the authors in April 2016. The subject of research is the attitude of parents of normal children to preschool inclusive education a child with Down syndrome based on their sociodemographic characteristics, level of education and awareness in the field of inclusion.
\end{abstract}

Keywords: inclusive education, Down syndrome, parents' attitudes to inclusive education.

\section{1. Введение}

На сегодняшний день проблема инвалидности вообе и детской инвалидности, в частности, весьма актуальна. С каждым годом всё чаще появляются на свет дети с таким диагнозом, как синдром Дауна (далее СД). По статистике, из 600-80о детей один младенец рождается на свет с СД. К сожалению, эта цифра постоянно увеличивается. По данным Росстата, в России на 2000 год было зарегистрировано 172,4 тыс. детей с врожденными пороками развития, деформации и хромосомных нарушений, а в 2013 году - 267,4 тыс. таких детей (Росстат).

Полноценное развитие ребёнка как неотъемлемое право человека и одна из важнейших задач образования на современном этапе требует поиска наиболее эффективных путей достижения этой цели. По закону N 273 Ф3 «Об образовании в Российской Федерации» от 29 декабря 2012 года* каждый ребенок, в том числе и ребенок с СД, имеет право обучаться в неспециализированных общеобразовательных учреждениях. «В целях реализации права каждого человека на образование федеральными государственными органами, органами государственной власти субъектов Российской Федерации и органами местного самоуправления: создаются необходимые условия для получения без дискриминации качественного образования лицами с ограниченными возможностями здоровья, для коррекции нарушений развития и социальной адаптации, оказания ранней

\footnotetext{
${ }^{*}$ Corresponding author

E-mail address: soc.gubina@gmail.com (S.A. Gubina), anser-23@bk.ru (A.N. Serebriakova), katerinafedorova25@ya.ru (E.A. Fedorova)

* [Электронный ресурc]. URL: https://rg.ru/2012/12/30/obrazovanie-dok.html
} 
коррекционной помощи на основе специальных педагогических подходов и наиболее подходящих для этих лиц языков, методов и способов общения и условия, в максимальной степени способствующие получению образования определенного уровня и определенной направленности, а также социальному развитию этих лиц, в том числе посредством организации инклюзивного образования лиц с ограниченными возможностями здоровья» (Консультант Плюс). Инклюзивное образование позволяет успешнее социализироваться детям с СД, а также воспитывать гуманное отношение обычных детей к таким детям.

Но у современного российского общества недостаточно сформирована практика дошкольного совместного обучения обычных детей с детьми с отклонениями от возрастной нормы развития, поскольку это связано, прежде всего, с неготовностью принимать «не таких детей» в систему массового образования: на юридическом уровне - нет законодательной базы; на уровне финансирования - не предусмотрены значительные материальные затраты на эти нужды; на уровне профессиональном - нехватка специалистов; на уровне общественного сознания не сформированы социально-психологические установки (Нестеренкова, 2012).

По данным исследования ФОМ 2012 года, только 45 \% россиян согласны с тем, что дети-инвалиды должны учиться с обычными детьми, 35 \% считают, что таким детям лучше учиться отдельно, 19 \% - затруднились ответить (ФОМ «Образование без границ», 2012). Полученные результаты свидетельствуют о том, «что внедрение инклюзивного образования сталкивается не только с трудностями организации так называемой «безбарьерной среды» (пандусов, одноэтажного дизайна учебного заведения, введения в штаты сурдопереводчиков, переоборудования мест общего пользования и т.п.), но и с препятствиями социального свойства, заключающимися в распространенных стереотипах и предрассудках» (Ярская-Смирнова, Лошакова, 2012), в том числе, в готовности или отказе воспитателей, детей и их родителей принять рассматриваемую форму образования.

Особую актуальность сегодня приобретают исследования общественного мнения о проблемах инклюзивного образования и способах их решения. Так, одной из задач нашего исследования было выяснение отношения родителей обычных детей к дошкольному инклюзивному образованию с детьми с синдромом Дауна.

\section{2. Материалы и методы}

Эмпирической базой исследования послужили количественный и качественный методы опроса родителей и воспитателей 2-х дошкольных учреждений г. Москвы, проведенный в апреле 2016 г. *

Количественное исследование. Количество родителей детей в возрасте 5-6 лет на 2015/2016 год составило 284 человека. Размер квотной выборки составил 240 человек. Использовался именно данный тип выборки, поскольку основными параметрами определения квот являлись возраст детей и наличие у родителей детей, обучающихся и не обучающихся в инклюзивной группе детского сада.

Качественное исследование проводилось на основе выборки доступных случаев с помощью глубинного интервью, целью которого являлся анализ мнения педагогического состава (воспитателей обычной и инклюзивной групп детского сада) о дошкольном инклюзивном образовании и о возможностях введения данного вида практики во всех дошкольных общеобразовательных учреждениях (4 экспертных интервью).

\section{3. Обсуждение}

Вопросам инклюзивного образования детей с нарушениями в развитии уделялось достаточно много внимания в работах отечественных психологов и педагогов. Л.С. Выготский (Выготский, 1983) уделял внимание развитию личности с различными отклонениями. О.Ф. Богатая, И.Ф. Павалаки, Н.П. Рассказова (Богатая и др., 2013) рассмотрели теоретические аспекты инклюзии, раскрыли организационные аспекты инклюзивной практики в дошкольном образовательном учреждении. С.А. Прушинский,

\footnotetext{
* Опрос проводился на базе дошкольного отделения ГБОУ «Гимназия № $1517 »$, ГОУ Детский сад № 1465 «Наш дом на Пресне», дошкольного структурного подразделения ГБОУ ЦО № 1678, ГБОУ Детский сад № 47.
} 
Ю.П. Симонова (Прушинский, Симонова, 2007) описали развитие инклюзивного образования, Н.Н. Малафеев (Малофеев, 2007) и К.А. Михальченко (Михальченко, 2012: 7779) выявили проблемы образования детей с различными видами нарушений.

В связи с популярностью темы инклюзивного образования в современном российском обществе активно разрабатываются программы обучения детей с нарушениями в развитии, в том числе, и с синдромом Дауна в дошкольных образовательных учреждениях. Так, Л.В. Кмытюк, С.П. Пичмев (Кмытюк, Пичмев, 2012) описали развитие и адаптацию детей с синдромом Дауна дошкольного возраста.

В современном обществе инклюзивным образованием принято считать такой вид организации процесса обучения, при котором все дети включены в единую систему образования и обучаются в общеобразовательных организациях общего типа, независимо от психических, физических и иных особенностей, где они получают необходимую поддержку и учитываются их особые образовательные потребности. Под инклюзивным образованием в широком смысле понимается совместное обучение обычных детей с детьми, которые чемлибо отличаются от них, например, национальностью, верой, социальным статусом и тому подобным. В узком смысле инклюзивное образование трактуется как совместное обучение обычных детей и детей с ограниченными возможностями здоровья (далее ОВЗ). В нашем исследовании мы будем рассматривать дошкольное инклюзивное образование как совместное обучение и воспитание детей с ограниченными возможностями здоровья и детей возрастной нормы в обычном детском саду.

На сегодняшний день в России существуют различные формы и виды дошкольного инклюзивного образования: дошкольные образовательные учреждения компенсирующего вида, детские сады комбинированного вида, детские сады, на базе которых реализуются дополнительные службы (лекотеки, службы ранней помощи, консультативный пункт), массовые дошкольные образовательные учреждения с группами кратковременного пребывания «Особый ребенок». В ДОУ компенсирующего вида, как правило, создается специализированная предметно-развивающая среда, учитывающая потребности детей определенной категории, и обучаются дети с определенной формой дезонтогенеза. В детских садах комбинированного вида обучаются дети, как возрастной нормы, так и дети, имеющие различные специфические образовательные потребности (Тенкачева, 2014).

Обучение детей с отклонениями в развитии в обычных массовых детских садах имеет ряд положительных сторон. Так, у обычных детей развиваются такие качества как, толерантное отношение, взаимопомощь, отзывчивость. Также дети будут с раннего возраста привыкать к тому, что в обществе рядом с ними могут находиться люди с различными особенностями (отклонениями) в развитии: интеллектуальными, психическими, физическими. Обычные дети научатся общаться и взаимодействовать с особыми детьми в процессе совместных игр, выполнения различных заданий. С другой стороны, для детей, имеющих ограничения по здоровью, обучение именно в массовых детских садах позволит успешнее социализироваться. Они будут подражать своим обычным сверстникам, учиться взаимодействовать не только с ближайшим окружением (семья, родственники), но и с ровесниками.

На сегодняшний день самой распространенной генетической аномалией является синдром Дауна, который вызван увеличением количества хромосом в клетках, поэтому этот врожденный синдром нельзя приобрести в течение жизни. Согласно статистическим данным, из 700 новорожденных 1 рождается с синдромом Дауна. Причем данный показатель одинаково распространен в различных странах, то есть, климат, социальное положение и раса не оказывают влияния на увеличение или уменьшение количества рожденных с синдромом Дауна. Возраст матери может стать существенным фактором увеличения данного показателя, но из-за того, что более молодые матери рожают чаще, родители детей с синдромом Дауна представлены во всех возрастных категориях (Петрова, 2015). Ребенок с синдромом Дауна может родиться в любой семье, независимо от ее социального положения, возраста родителей (Мифы и правда).

Дети с данным синдромом часто болеют, тяжело переносят детские инфекции, так как, y них ослабленный иммунитет, также у них имеются нарушения интеллектуального развития (умственная отсталость, недоразвитость речи), проблемы с моторным и физическим развитием. 


\section{4. Результаты}

Сравнение представлений родителей «обычной группы» и «инклюзивной группы» о дошкольном инклюзивном образовании

В современном российском обществе инклюзивное образование только начинает развиваться и внедряться массово в дошкольные учреждения. Данная практика уже используется в массовых школах и только в последние несколько лет, в детских садах.

Так, по данным нашего опроса, только 30,6 \% родителей детей «инклюзивной группы» детского сада правильно трактуют понятие «инклюзивное образование», 5 \% респондентов затруднились дать ответ на поставленный вопрос. Процент (22,7 \%) родителей детей «обычной группы», информированных об инклюзивном образовании несколько ниже. Это связано с тем, что, даже обучая детей в одном детском саду, не все родители знают о наличии в нем инклюзивных групп. 53,1 \% родителей женского пола имеют правильное представление о сути понятия инклюзивного образования, в отличие от родителей мужского пола $-46,9 \%$.

Примечательным является и тот факт, что информированность о практике инклюзивного образования напрямую зависит от уровня образования респондента. Так, 64,1 \% родителей с высшим образованием правильно трактуют понятие «инклюзивное образование», понимая его как совместное обучение обычных детей и детей с нарушениями в развитии.

Еще одним фактором, влияющим на информированность об инклюзивном образовании, является наличие опыта инклюзивного обучения у детей. 57,8 \% опрошенных родителей детей инклюзивной группы дали верный ответ на вопрос о трактовке понятия инклюзивного образования, в отличие от родителей детей обычной группы - 42,2 \% опрошенных.

Таким образом, чем выше уровень образования, тем больше родители осведомлены об инклюзивном образовании. Родители, дети которых обучаются в инклюзивной группе детского сада, имеют верное понимание сути инклюзивного образования, чем родители детей, не имеющих такого опыта. Родители женского пола значительно чаще правильно трактовали понятие инклюзивного образования, в отличие от родителей мужского пола в силу большей включенности в воспитание ребенка и жизнь детского сада.

\section{Представления родителей обычных детей о дошкольном инклюзивном образовании.}

Одной из проблем, которая влияет на отношение родителей детей, обучающихся в обычной группе детского сада к дошкольному инклюзивному образованию, является различие представлений о преимуществах и недостатках данной практики, о решении проблемы адаптации детей с СД, об условиях введения инклюзивного образования в массовых детских садах, а также в определении конкретных способов взаимодействия обычных детей и детей с ограниченными возможностями (синдром Дауна).

Респонденты указали несколько способов взаимодействия обычных детей и ребенка с СД. Среди них лидирующие позиции занимают случайное общение на улице(38,o \%), общение на совместных мероприятиях $(37,8$ \%) и совместные игры во дворе и на улице (35,3\%). Только 13,4 \% респондентов считают, что обычные дети и ребенок с СД могут воспитываться в одной группе детского сада, а 19,3 \% убеждены, что эти дети не должны взаимодействовать никаким образом. Воспитатели полагают, что важно проводить беседы с родителями о пользе инклюзивного образования в детских садах для всех детей, как для обычных, так и для особых: «...рассказать о сути образования, что это может дать детям, что будет работать логопед, сопровождающий, не просто посадят этого ребенка, а создадут специальные условия; объяснять им, что дети с синдромом Дауна добрые и такие же, как все остальные» (мнение воспитателя обычной группы детского сада № 3).

Среди способов адаптации детей с синдромом Дауна к жизни в обществе родители обычных детей отмечают различные их варианты. Только 24,4 \% опрошенных родителей детей обычной группы детского сада считают, что дети с синдромом Дауна должны обучаться с обычными детьми, Каждый пятый (21,0 \%) считает возможность обучения вместе с обычными детьми при условии посещения специалистов, большинство же (39,5 \%), что такие дети должны учиться в специализированных учреждениях, 8,4 \% - дома 
и 6,7 \% затруднились ответить. Это означает, что родители детей обычной группы детского сада убеждены в необходимости обучения детей с синдромом Дауна в специализированных учреждениях.

\section{Представления родителей «обычной группы» об условиях введения инклюзивного образования и необходимых знаниях и навыках воспитателей.}

Родители обычных детей в качестве наиболее значимых условий введения инклюзивного образования в детских садах отмечают разработку специальных образовательных программ, формирование положительного общественного мнения, увеличение времени, отведенного на образовательную деятельность, дополнительную профессиональную подготовку воспитателей и приобретение дополнительных обучающих игр и материалов (см. Рис. 1). Это связано с тем, что для внедрения данного вида образования необходимо оборудовать помещение, подготовить персонал и родителей.

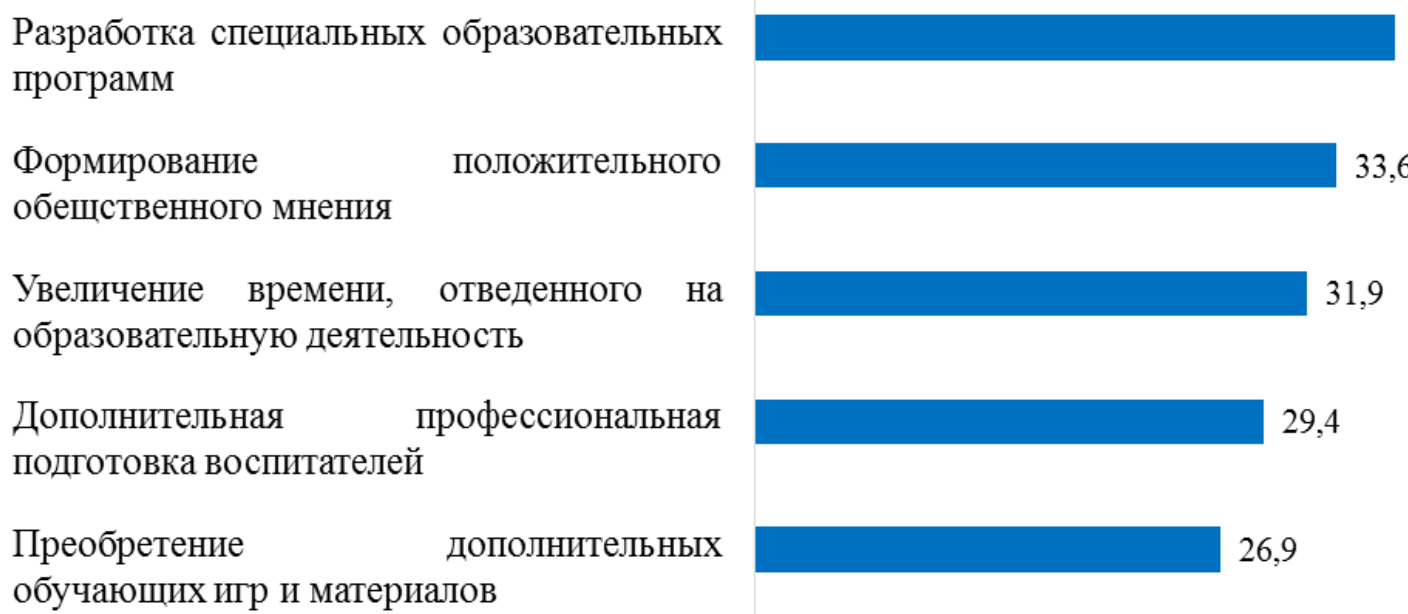

Рис. 1. Условия введения инклюзивного образования в детских садах, по мнению родителей (в \% от числа опрошенных родителей детей обычной группы детского сада; допускалось несколько вариантов ответа; ранжировано по убыванию)

По мнению родителей обычных детей, дополнительная профессиональная подготовка воспитателей является одним из наиболее важных условий введения инклюзивного образования в детских садах. При этом, у воспитателей инклюзивных групп детских садов, в которых обучается ребенок с СД, должны быть сформированы специальные знания и навыки об особенностях развития детей с этим заболеванием (37,0 \% от числа ответивших), восприятие ребенка с СД наравне с другими детьми в группе (33,6 \% от числа ответивших), умение налаживать контакт со всеми детьми и умение осуществлять индивидуальный подход к детям (31,1 \%, 31,1 \% от числа ответивших, соответственно).

Родители обычных детей выделили несколько преимуществ и недостатков совместного обучения обычных детей с ребенком с СД. 35,3 \% ответивших считают, что их дети научатся взаимодействовать с особыми детьми, 28,6 \% - не видят положительных моментов и 23,5 \% ответивших полагают, что дети с синдромом Дауна приобретут необходимые навыки и качества (см. Рис. 2). Следовательно, почти треть родителей не видят преимуществ от дошкольного инклюзивного образования для детей. Связано это, прежде всего, с тем, что дети этих родителей не имеют опыта обучения в инклюзивной группе детского сада, а значит, представления родителей могут отличаться от реальной ситуации в таких группах. Однако мнение воспитателя об изменениях в связи с введением инклюзивной группы в детском саду говорит об обратном: «Во-первых, больше появилось материала для размышления, как родителям, так и детям... и для воспитателя большая подготовка, каждый день он должен доводить до особого ребенка знания. У детей разные способности выполнять ту или иную работу, поэтому нужно распланировать работу, чтобы она была 
интересна и тем, и другим, материал должен быть наглядным. Для воспитателя стало труднее, так как, больше времени уходит на подготовку занятий. В то же время, воспитатель может наблюдать за результатом воздействия на детей: добился ли он того, что дети стали более милосердными и доброжелательными по отношению к особым детям?» (воспитатель инклюзивной группы д/с №4).

Дети научатся взаимодействовать с особыми детьми

Дети с синдромом Дауна приобретут необходимые навыки, качества

Нет положительных моментов

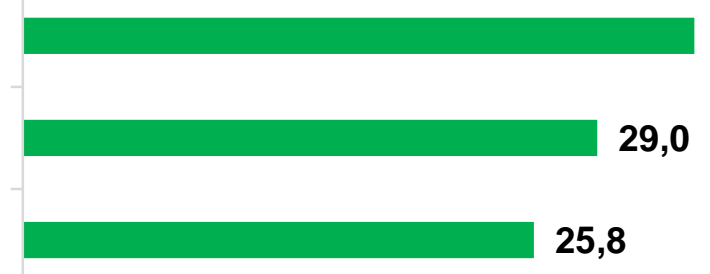

Рис. 2. Преимущества совместного дошкольного обучения обычных детей и ребенка с синдромом Дауна по мнению родителей (в \% от числа ответивших; допускалось несколько вариантов ответа; ранжировано по убыванию)

К недостаткам совместного обучения обычных детей и ребенка с СД родители отнесли снижение у детей интереса к занятиям познавательного цикла, снижение успеваемости и темпов развития у обычных детей, ухудшение самочувствия детей с синдромом Дауна и снижение внимания к обычным детям со стороны воспитателей. Следовательно, родители обычных детей предполагают, что программа инклюзивного образования в детских садах не способствует развитию всех детей: отрицательно сказывается на успеваемости обычных детей и на самочувствии детей с СД (см. Рис.3).

Снижение у детей интереса к занятиям познавательного цикла

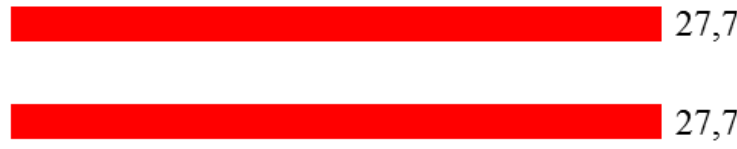

Снижение успеваемости и темпов развития у обычных детей 27,7

Ухудшение самочувствия детей с синдрором Дауна

Снижение внимания к обычным детям со стороны воспитателей

Рис. 3. Недостатки совместного дошкольного обучения обычных детей и ребенка с синдромом Дауна по мнению родителей (в \% от числа ответивших; допускалось несколько вариантов ответа; ранжировано по убыванию)

Таким образом, родители детей обычной группы детского сада считают, что дети с СД в основном должны обучаться в специализированных учреждениях. Обычные дети, по мнению респондентов, могут общаться с ребенком с СД исключительно на улице (совместные игры и случайное общение) или на совместных мероприятиях (праздниках). Около трети респондентов полагают, что положительные моменты при совместном обучении обычных детей и ребенка с СД отсутствуют. Это объясняется тем, что обычным детям уделяется недостаточно внимания со стороны воспитателей, а также снижается успеваемость обычных детей и ухудшается самочувствие ребенка с синдромом Дауна.

Следовательно, исходя из вышесказанного, родители обычных детей в современных условиях, в основном, не готовы принять практику инклюзивного образования в детских садах. По мнению воспитателя, отношение родителей обычных детей зависит от того, что хочет получить родитель от обучения ребенка в детском саду, а также от самих родителей: «80 \% будут против, потому что сами родители делятся на разные группы: толерантные по своей сути и воспитанные, они будут «за», другие - карьеристы, они будут биться за то, чтобы их ребенок получил лучшее образование. Неодинаковые родители, поэтому неодинаковый подход к введению инклюзивного образования. Они не понимают того, что 
их дети, общаясь с детьми с синдромом Дауна, становятся толерантными, добрыми» (воспитатель обычной группы детского сада № 3). Воспитатели убеждены, что родители еще не готовы к нововведениям в детских садах, в том числе, и к инклюзивному образованию, так как, разный уровень развития детей скажется и на уровне образования группы в целом: «Не все готовы принять данные изменения. Каждый родитель хочет, чтобы ребенок воспитывался в учреждении с высоким уровнем образования, что будет затруднительно осуществлять при наличии разных возможностей детей, по причине здоровья» (воспитатель обычной группы детского сада №2).

\section{Оценка опыта родителей обычных детей, обучающихся в инклюзивной группе детского сада.}

Отношение родителей к дошкольному инклюзивному образованию во многом зависит от наличия опыта. Абсолютное большинство родителей отметили, что их дети обучаются в инклюзивной группе, как минимум, два года. Когда родители узнали о том, что их ребенок зачислен в инклюзивную группу детского сада, их реакция была различной. Относительное большинство респондентов испытывали сочувствие, сопереживание (27,3\%), заинтересованность (24,0 \%), спокойствие $(19,8 \%)$. Но были и такие родители, которые чувствовали в тот момент тревогу, обеспокоенность (9,1\%), удивление $(7,4 \%)$, растерянность $(5,8)$, испытывали чувство неловкости $(5,0$ \%) и даже безразличия $(5,0 \%)$.

15,7 \% ответивших указали на наличие сложностей в процессе совместного обучения их ребенка и ребенка с СД. На Рис. 4 представлены сложности, которые возникали у детей в процессе обучения в инклюзивной группе детского сада, по мнению их родителей.

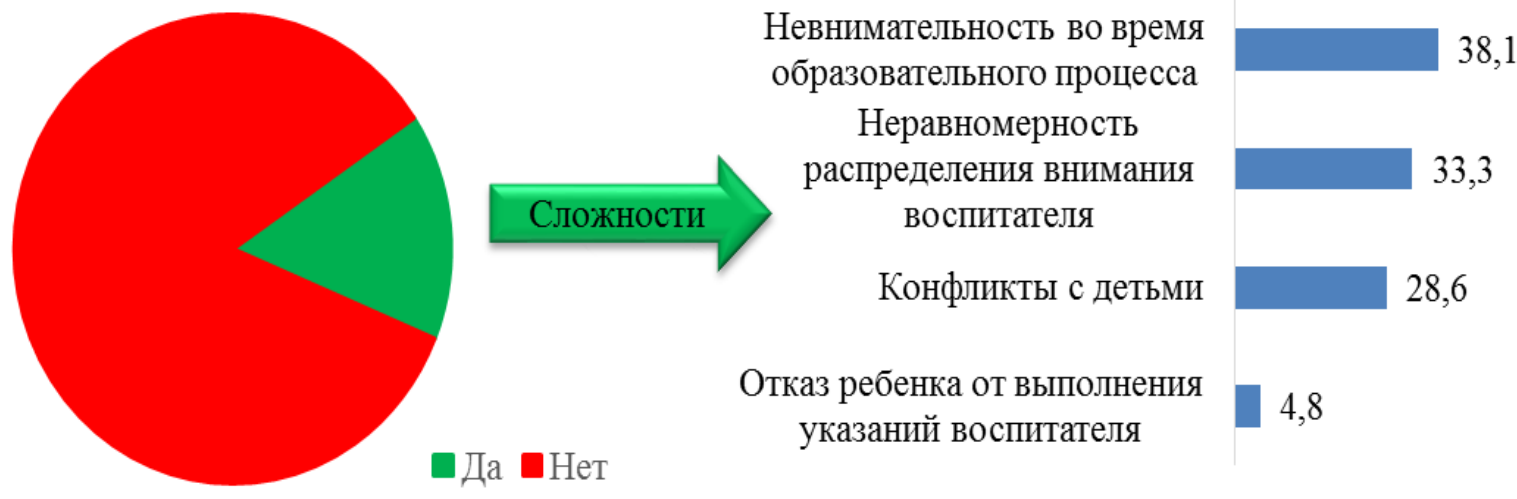

Рис. 4. Сложности в инклюзивной группе у детей, по мнению их родителей (в \% от числа ответивших; допускалось несколько вариантов ответа; ранжировано по убыванию)

Родители отмечали изменение в поведении своих детей после обучения в инклюзивной группе детского сада. Относительное большинство родителей отметили, что их ребенок стал дружелюбнее (34,5 \%). При этом 29,4 \% ответивших респондентов считают, что поведение их ребенка никак не изменилось после обучения в такой группе. Несмотря на это, у детей, по мнению их родителей, сформировались такие, в основном, положительные качества, как: общительность (35,3 \%), доброжелательность $(34,5 \%)$, забота о других $(29,4 \%)$, отзывчивость $(27,7 \%)$, дисциплинированность $(25,2 \%)$, вежливость $(24,4 \%)$, самостоятельность (23,5 \%), внимательность (21,8 \%), исполнительность (18,5 \%).

Родители считают, что дети с СД также имеют преимущества от дошкольного инклюзивного образования. 42,5 \% респондентов полагают, что такой ребенок научится взаимодействовать с обычными детьми с раннего возраста, 40,8 \% - сможет получить дополнительную поддержку со стороны сверстников, 37,5\% - будет чувствовать себя более полноценно, участвуя в жизни детского коллектива наравне с другими детьми, 33,3 \% будет активно развиваться, 31,7 \% - появится больше возможностей проявить свои способности в различных видах деятельности.

Безусловно, за время обучения детей в инклюзивной группе отношение родителей могло меняться в зависимости от возникновения различных сложностей или наоборот, 
положительного результата для их ребенка. Так, у 55,5 \% респондентов, отношение к дошкольному инклюзивному образованию изменилось в положительную сторону, у 38,7 \% осталось неизменным, 1,7 \% изменили свое отношение в худшую сторону, а 4,2 \% затруднились ответить на данный вопрос.

Таким образом, наше предположение о том, что на формирование толерантного отношения родителей к дошкольному инклюзивному образованию оказывают влияние такие социокультурные факторы, как информированность о практике дошкольного инклюзивного образования, наличие опыта и уровень образования родителей в результате исследования полностью подтвердилось. Так, родители, имеющие высшее образование, дети которых обучаются в инклюзивной группе детского сада, относятся к данному виду практики в целом положительно. По их мнению, в группе детей иногда возникают сложности, но при этом они становятся дружелюбнее, учатся взаимодействовать и помогать друг другу. В то время, как родители детей обычной группы считают, что дети с синдромом Дауна должны обучаться в специализированных учреждениях, а инклюзивное образование не принесет пользы ни обычным, ни особым детям.

\section{5. Заключение}

Дошкольное инклюзивное образование имеет ряд преимуществ и недостатков. Среди преимуществ можно выделить формирование у обычных детей навыков взаимодействия с ребенком не возрастной нормы развития (синдром Дауна), приобщение детей с ограниченными возможностями здоровья к окружающим его сверстникам и взрослым. К недостаткам относятся: снижение образовательного уровня развития и подготовки всей группы детей и отсутствие грамотного распределения внимания воспитателя по отношению, как к обычным, так и особым детям.

С целью формирования положительного отношения к практике инклюзивного образования в дошкольных общеобразовательных учреждениях, на основе анализа интервью и данных анкетного опроса, были разработаны следующие рекомендации по улучшению способов информирования родителей о данной практике образовательного процесса:

- Проведение совместных мероприятий (праздников) для детей с ОВЗ и детей возрастной нормы развития.

- Информирование всех родителей о дошкольном инклюзивном образовании и о положительном опыте внедрения данного вида образовательной практики в других детских садах.

- Профессиональная (пере-)подготовка воспитателей (повышение уровня квалификации, обучение для работы с детьми разной возрастной нормы развития).

- Создание материально-технической и усовершенствование законодательной баз дошкольного инклюзивного образования.

- Информирование родителей об особенностях детей с ограниченными возможностями здоровья.

\section{Литература}

Богатая и др., 2013 - Богатая О.Ф., Павалаки И.Ф., Рассказова Н.П. Организация инклюзивного образования детей с ограниченными возможностями здоровья в дошкольных образовательных учреждениях. Тюмень: Аксиома, 2013. 92 с.

Выготский, 1983 - Выготский Л.С. Собрание сочинений в 6 т.: Т.5: Основы дефектологии. 1983. 369 с.

Кмытюк, Пичмев, 2012 - Кмытюк Л.В., Пичмев С.П. Comenius-420. Международный проект. Особенный ребенок в образовательном пространстве города. Создание оптимальных условий для комплексного сопровождения ребенка с синдромом Дауна. М., 2012. 68 с.

Консультант Плюс - Консультант Плюс [Электронный pecypc]. URL: http://www.base.consultant.ru/cons/cgi/online.cgi?req=doc;base=LAW;n=182943;fld=134;dst=1 ooo79,0;rnd $=0.025494243949651718$ 
Малофеев, 2007 - Малофеев Н.Н. Особый ребенок - вчера, сегодня и завтра. (Образование и психолого-педагогическая помощь детям с ограниченными возможностями здоровья в 20 веке), ГНУ «Институт коррекционной педагогики», 2007. 97 с.

Мифы и правда - Мифы и правда [Электронный ресурс] URL: https://downsideup.org/ru/sindrom-dauna/mify-i-pravda

Михальченко, 2012 - Михальченко К.А. Инклюзивное образование - проблемы и пути решения / Теория и практика образования в современном мире: материалы междунар. заоч. науч. конф. (г. Санкт-Петербург, февраль 2012 г.). СПб.: Реноме, 2012. С. 77-79.

Нестеренкова, 2012 - Нестеренкова О. Равные и разные: инклюзия от мечты к реальности // Пионер, №11. Март 2012 г. С. 6-9.

Петрова, 2015 - Петрова А.Д. Проблемы реабилитации и социальной адаптации детей с синдромом Дауна // Личность, семья и общество: вопросы педагогики и психологии. № 9-10 (55), 2015. C. 63. [Электронный pecypc]. URL: http://www.cyberleninka. $\mathrm{ru} /$ article/n/problemy-reabilitatsii-i-sotsialnoy-adaptatsii-detey-s-sindromom-dauna

Прушинский, Симонова, 2007 - Прушинский С.А., Симонова Ю.П. Развитие инклюзивного образования: сб. материалов / сост. С.А. Прушинский, Ю.П. Симонова. М.: Перспектива, 2007.

Росстат - Росстат [Электронный pecypc]. URL: http://www.gks.ru/wps/wcm /connect/rosstat_main/rosstat/ru/statistics/population/motherhood/\#

Тенкачева, 2014 - Тенкачева T.P. Инклюзивное образование детей дошкольного возраста в России // Педагогическое образование в России, № 1, 2014. С. 208. [Электронный pecypc]. URL: http://cyberleninka.ru/article/n/inklyuzivnoe-obrazovanie-detey-doshkolnogovozrasta-v-rossii

ФОМ «Образование без границ», 2012 - ФОМ «Образование без границ», 2012. [Электронный ресурc]. URL: http://www.fom.ru/Nauka-i-obrazovanie/10588

Ярская-Смирнова, Лошакова, 2012 - Ярская-Смирнова Е.Р., Лошакова И.И. Инклюзивное образование детей-инвалидов, 2012. [Электронный ресурc]. URL: http://dislife.ru/articles/view/19738

\section{References}

Bogataya i dr., 2013 - Bogataya, O.F., Pavalaki, I.F., Rasskazova, N.P. (2013). Organizatsiya inklyuzivnogo obrazovaniya detei s ogranichennymi vozmozhnostyami zdorov'ya v doshkol'nykh obrazovatel'nykh uchrezhdeniyakh [Organization of inclusive education of children with disabilities in preschool educational institutions]. Tyumen': Aksioma, $92 \mathrm{s.}$

Vygotskii, 1983 - Vygotskii, L.S. (1983). Sobranie sochinenii v 6 t [Works in 6 T.].: T. 5: Osnovy defektologii. $369 \mathrm{~s}$.

Kmytyuk, Pichmev, 2012 - Kmytyuk, L.V., Pichmev, S.P. (2012). Comenius-420. Mezhdunarodnyi proekt. Osobennyi rebenok v obrazovatel'nom prostranstve goroda. Sozdanie optimal'nykh uslovii dlya kompleksnogo soprovozhdeniya rebenka $\mathrm{s}$ sindromom Dauna [The international project. A special child in the educational space of the city. The creation of optimal conditions for the comprehensive support of a child with Down syndrome]. M., $68 \mathrm{~s}$.

Konsul'tant Plyus - Konsul'tant Plyus [Elektronnyi resurs]. URL: http://www.base. consultant.ru/cons/cgi/online.cgi?req=doc;base $=\mathrm{LAW} ; \mathrm{n}=182943 ; \mathrm{fld}=134 ; \mathrm{dst}=100079,0 ; \mathrm{rnd}=0.0$ 25494243949651718

Malofeev, 2007 - Malofeev, N.N. (2007). Osobyi rebenok - vchera, segodnya i zavtra. (Obrazovanie i psikhologo-pedagogicheskaya pomoshch' detyam s ogranichennymi vozmozhnostyami zdorov'ya v 20 veke) [Special child - yesterday, today and tomorrow. (Education and psycho-pedagogical assistance to children with disabilities in the 20th century)], GNU «Institut korrektsionnoi pedagogiki», $97 \mathrm{~s}$.

Mify i pravda - Mify i pravda [Elektronnyi resurs] URL: https://downsideup.org /ru/sindrom-dauna/mify-i-pravda

Mikhal'chenko, 2012 - Mikhal'chenko, K.A. (2012). Inklyuzivnoe obrazovanie - problemy i puti resheniya [Inclusive education - problems and solutions]. Teoriya i praktika obrazovaniya $v$ sovremennom mire: materialy mezhdunar. zaoch. nauch. konf. (g. Sankt-Peterburg, fevral' 2012 g.). SPb.: Renome, 2012. S. 77-79. 
Nesterenkova, 2012 - Nesterenkova, O. (2012). Ravnye i raznye: inklyuziya ot mechty k real'nosti [Equal and different: inclusion from dream to reality]. Pioner. 11: 6-9.

Petrova, 2015 - Petrova, A.D. Problemy reabilitatsii i sotsial'noi adaptatsii detei s sindromom Dauna [The Problem of rehabilitation and social adaptation of children with Down syndrome]. Lichnost', sem'ya i obshchestvo: voprosy pedagogiki i psikhologii. № 9-10 (55), 2015. S. 63 . [Elektronnyi resurs]. URL: http://www.cyberleninka. ru/article/n/problemy-reabilitatsii-isotsialnoy-adaptatsii-detey-s-sindromom-dauna

Prushinskii, Simonova, 2007 - Prushinskii, S.A., Simonova, Yu.P. (2007). Razvitie inklyuzivnogo obrazovaniya [Development of inclusive education]: sb. materialov. sost. S.A. Prushinskii, Yu.P. Simonova. M.: Perspektiva.

Rosstat - Rosstat [Elektronnyi resurs]. URL: http://www.gks.ru/wps/wcm/connect /rosstat_main/rosstat/ru/statistics/population/motherhood/\#

Tenkacheva, 2014 - Tenkacheva, T.R. (2014). Inklyuzivnoe obrazovanie detei doshkol'nogo vozrasta v Rossii [Inclusive education of children of preschool age in Russia]. Pedagogicheskoe obrazovanie $v$ Rossii. 1: 208. [Elektronnyi resurs]. URL: http://cyberleninka.ru/article/n/i nklyuzivnoe-obrazovanie-detey-doshkolnogo-vozrasta-v-rossii

FOM «Obrazovanie bez granits», 2012 - FOM «Obrazovanie bez granits», 2012. [Elektronnyi resurs]. URL: http://www.fom.ru/Nauka-i-obrazovanie/10588

Yarskaya-Smirnova, Loshakova, 2012 - Yarskaya-Smirnova, E.R., Loshakova, I.I. (2012). Inklyuzivnoe obrazovanie detei-invalidov [Inclusive education of children with disabilities]. [Elektronnyi resurs]. URL: http://dislife.ru/articles/view/19738

\title{
Отношение родителей к дошкольному инклюзивному образованию обычных детей и ребенка с синдромом Дауна
}

\author{
Светлана Александровна Губина ${ }^{\text {a }}$, , Анастасия Николаевна Серебрякова а, \\ Екатерина Алексеевна Федорова ${ }^{\text {a }}$ \\ a Российский химико-технологический университет им. Д.И. Менделеева, \\ Российская Федерация
}

Аннотация. Объектом исследования является дошкольное инклюзивное образование - такой вид организации процесса обучения, при котором все дети включены в единую систему образования и обучаются в общеобразовательных организациях общего типа, независимо от психических, физических и иных особенностей, где они получают необходимую поддержку и учитываются их особые образовательные потребности (дети с синдромом Дауна). Основным источником эмпирических данных стали количественный и качественный методы опроса родителей и воспитателей инклюзивных групп детских садов г. Москвы, проведенный авторами в апреле 2016 года. Предметом исследования является отношение родителей обычных детей к дошкольному инклюзивному образованию с ребенком с синдромом Дауна, основанное на их социально-демографических характеристиках, уровне образования и информированности в области инклюзии.

Ключевые слова: инклюзивное образование, синдром Дауна, отношение родителей к инклюзивному образованию.

\footnotetext{
${ }^{*}$ Корреспондирующий автор Адреса электронной почты: soc.gubina@gmail.com (S.A. Gubina), anser-23@bk.ru (A.N. Serebriakova), katerinafedorova25@ya.ru (E.A. Fedorova)
} 